\title{
CADM2 wt Allele
}

National Cancer Institute

\section{Source}

National Cancer Institute. CADM2 wt Allele. NCI Thesaurus. Code C95845.

Human CADM2 wild-type allele is located in the vicinity of 3p12.1 and is approximately $1115 \mathrm{~kb}$ in length. This allele, which encodes cell adhesion molecule 2 protein, plays a role in the modulation of both cell adhesion and adherens junction formation. 